\title{
Treatment of a subepiglottic cyst with formaldehyde injection in a horse
}

\section{Tratamento de cisto subepiglótico em eqüino com injeção de formaldeído}

\author{
Paula de Mattos Guttmann, ${ }^{*}$ Márcia T. Ramos, ${ }^{* *}$ Gabriela de Vasconcelos Costa Lobato, ${ }^{*}$ Daniel Augusto Barro Lessa*
}

\begin{abstract}
Subepiglottic cysts may cause airway obstruction and/or dysphagia. Intralesional formaldehyde application has been successfully done using double application. This paper describes treatment using a single application. This procedure minimizes complications related to scar tissue formation and general anesthesia, and allows earlier return to athletic activity.
\end{abstract}

Keywords: subepiglottic cyst, equine, formaldehyde.

\section{Resumo}

Cistos subepiglóticos podem causar obstrução das vias aéreas e/ou disfagia. A aplicação intralesional de formaldeído já foi realizada com sucesso usando dupla aplicação. Este trabalho descreve o tratamento usando uma única aplicação. Esse procedimento minimiza complicações relacionadas à formação de cicatrizes e anestesia geral, e permite um retorno mais rápido às atividades atléticas.

Palavras-chave: cisto subepiglótico, equino, formaldeído.

\section{Introduction}

Subepiglottic cysts are an uncommon cause of upper airway noise and exercise intolerance in the horse (Davenport-Goodall and Parente, 2003). Although infrequent, cystic structures in the horse's pharynx can cause a variety of clinical signs, such as dysphagia, choke, airway obstruction and external swelling (Robertson, 2007).

Cysts involving the pharynx, soft palate, guttural pouches and larynx can be identified by upper airway endoscopy and standing radiographs (Davenport-Goodall and Parente, 2003; Robertson, 2007). Cysts can be located dorsally on the soft palate, in the subepiglottic area. They can be of varying size, loosely attached and may disappear intermittently as the horse swallows. They are usually fluctuant and present a smooth contour.

Surgical and non-surgical treatments have been described. Intralesional formalin injection has been used for the treatment of a large based subepiglottic cyst using two applications 14 days apart, since surgery was not an option due to economic constraints (Dougherty and Palmer, 2008). Surgical options include cyst removal, either by oral approach or laryngotomy. Transendoscopic laser ablation and snare excision have also been described (Davenport-Goodall and Parente, 2003). Marsupialisation or establishment of chronic drainage are alternatives to complete removal, if surgical access is inadequate or if there is risk of damaging vital structures (Robertson, 2007).

Non-surgical treatment offers advantages over surgical procedures, such as faster return to performance, especially if compared to a laryngotomy, and reduced risk of scar tissue formation on the larynx, which can disrupt the function of the soft palate and result in its dorsal displacement (Davenport-Goodall and Parente, 2003).

This case report describes the treatment of a subepiglottic cyst in a horse, using one application of intralesional formalin. To our knowledge this is the first report of a single formalin injection to treat this kind of cyst in horses.

\section{Case report}

A two year old male thoroughbred racehorse showed respiratory stridor during exercise. At physical exam at rest, respiratory rate was $16 \mathrm{mpm}$, and there was no abnormal respiratory noise. The horse did not present coughing or dysphagia. An endoscopic exam was performed and intermittent soft palate displacement was observed. The free border of the soft palate was edematous and contained small ulcers. After swallowing, the soft palate was repositioned and the epiglottis appeared normal. A cyst was visualized on the left ventral aspect of the epiglottis. The cyst was wide based fluctuant in consistence, measuring approximate one half of the length of epiglottis and seemed to be large based.

The horse was sedated with $200 \mathrm{mg}$ of xylazine hydrochloride intravenously and a laryngoscopy was performed. Local anesthesia was achieved by topical instillation of $10 \mathrm{ml}$ of $2 \%$ lidocaine hydrochloride using a double lumen catheter with a needle attached to its distal extremity (Lance-a-lot, Mila International), which had been previously passed through

\footnotetext{
* Faculdade de Veterinária, Universidade Federal Fluminense. Rua Vital Brazil Filho, 65, Vital Brazil, 24.320-340. Niterói, RJ.

** Instituto de Veterinária, Universidade Federal Rural do Rio de Janeiro. BR-465, km 7, Seropédica, RJ 23890-000.
} 
the instrument channel of the endoscope (Olympus PQ20 gastroscope). After lowering the horses head, the catheter was exteriorized into the pharynx, the needle was exposed and advanced to puncture the cyst. After unsuccessful attempt to aspirate the cyst, approximately $6 \mathrm{ml}$ of $10 \%$ formaldehyde was injected into it. Formaldehyde was injected until resistance was achieved. Both catheter and needle were removed from the endoscope, and pharyngeal region was washed with one liter of $0,9 \%$ saline solution through the endoscope's instrument channel. After endoscope removal while the patient's head was still down, yellow gelatinous bilateral rhinorrhea was observed. The horse was medicated with phenylbutazone $(2 \mathrm{~g}$, SID, intravenous) for 3 days following the procedure and aerosolized beclomethasone dipropionate $(2.0 \mu \mathrm{g} / \mathrm{kg}$ BID) using a spacer device (Equine Haler TM) was applied for seven days. No undesired reactions were noticed, such as dysphagia, coughing or fever on the following days.

Follow-up endoscopic exams were performed 7, 15 and 30 days post-procedure. On the first exam, the cyst was enlarged and hyperemic. On the second exam, the cyst was flaccid and showed normal coloration. On the third exam, the cyst was absent.

The horse was kept at rest during a 30 day period. Once exercise started, no abnormal respiratory noise was noticed. The horse's athletic performance was normally resumed. Eight months later, a follow-up endoscopic examination revealed normal anatomic structures and absence of scar tissue or cyst recurrence.

\section{Discussion and conclusion}

Pharyngeal cysts are usually located in the subepiglottic area, and rarely occur on the dorsal pharynx, larynx and soft palate. Diagnosis is made by endoscopic examination, since the cysts are usually situated under or slightly lateral to the epiglottis. However, if cyst is located under the caudal margin of the soft palate or if the soft palate is displaced over the epiglottis, visualization might be difficult (Robertson, 1991). In this case, the position of the cyst was probably interfering with soft palate

\section{References}

DAVENPORT-GOODALL, C.L.M.; PARENTE, E.J. Disorders of the Larynx. The Veterinary Clinics Equine Practice, v.19, p.169-187, 2003.

DOUGHERTY, S.S.; PALMER, J.L. Use of intralesional formalin administration for treatment of a subepiglottic cyst in a horse. Journal of American Veterinary Medical Association, v. 233, n. 3, p. 463-465, 2008.

ROBERTSON, J.T. Surgical treatment of developmental cysts of the pharynx, larynx and the cervical region of the horse. Equine Veterinary Education, v.19, p. 137-138, 2007.

ROBERTSON, JT. Pharynx and Larynx. In: BEECH J. (ed.) Equine Respiratory Disorders. Pennsylvania: Lea \& Febiger, 1991, p. 331387.

SCHUMACHER, J.; HONNAS, C.; YARBROUGH, T.; PASCOE, J.; MEAGHER, D.; WOODS, P. Ablation of Progressive Ethmoidal Hematomas of Horses by Intralesional Injection of Formaldehyde Solution. In: CONVENTION OF THE AMERICAN ASSOCIATION functioning, causing intermittent displacement and small ulcers on its free border.

Although complete surgical excision has been described as the most effective method of treatment for subepiglottic cysts (Davenport-Goodall and Parente, 2003), successful nonsurgical treatment has been done with the use of intralesional formaldehyde injection in two applications 14 days apart (Dougherty and Palmer, 2008).

In this particular case, one application of $10 \%$ formalin was sufficient to achieve cyst involution. Based on the volume infused, cyst in this case was smaller than the one previously described (Dougherty and Palmer, 2008), and the horse did not present clinical signs other than respiratory stridor during exercise associated to the cyst. A second application was delayed since the cyst was smaller and more flaccid on the second endoscopic exam on day 15 post-application, and the horse remained clinically normal. On day 30 , since the cyst was no longer visualized, there was no need to repeat the procedure.

Dougherty and Palmer (2008) performed a second injection 14 days post first injection, although the cyst showed $50 \%$ reduction in size, but the horse still had mucoid bilateral nasal discharge. This shows that the need of a second injection will depend on the appearance of the cyst and the clinical signs that remain on the follow up examination.

Performing the procedure with standing sedation unquestionably excludes risks associated to general anesthesia. The procedure was well tolerated by the horse, but sedation and restraint needs to be effective, since any small movement interferes with correct needle placement. The yellow gelatinous bilateral rhinorrhea observed following the procedure was resolved within a few hours.

The single application precludes the need of additional sedation and reduces possible formalin systemic and neurotoxicity (Songur et al., 2010). The formation of minimum scar tissue, to the point where it is not visible on endoscopic exam, preserves physiologic epiglottic function and no airway obstruction, allowing complete return to athletic performance.

OF EQUINE PRACTITIONERS, 43., 1997, EUA. Proceedings of American Association Equine Practitioners, 1997. p. 244-245.

SELLON, D.C.; TAYLOR, E.L.; WARDROP, J.; KINGSTON, J.; HINES, T.M. The Effects of Intravenous Formaldehyde on Hemostasis in Normal Horses. CONVENTION OF THE AMERICAN ASSOCIATION OF EQUINE PRACTITIONERS, 45., 1999, EUA. Proceedings of American Association of Equine Practitioners, 1999. p. 297-298.

SILVA, L.C.L.C.; SIQUEIRA, R.F.; ZOPPA, A.L.V. Chemical Ablation Of An Extensive Ethmoidal Hematoma In A Horse Using $10 \%$ Formalin - Case Report. CONGRESS OF THE WORLD EQUINE VETERINARY ASSOCIATION, 11., 2009, Brasil. In: PROCEEDINGS OF THE 11TH INTERNATIONAL CONGRESS OF WORLD EQUINE VETERINARY ASSOCIATION, 2009. CDROM.

SONGUR, A.; OZEN, O.A.; SARSILMAZ, M. The toxic effects of formaldehyde on the nervous system. Reviews of Environmental Contamination and Toxicology, v.103, p.105-118, 2010. 